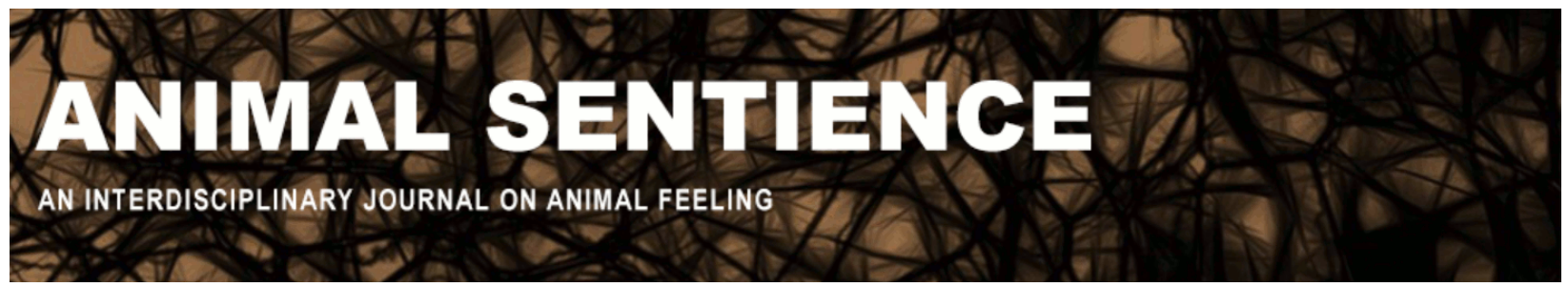

Hermanson, Sean (2019) The problem is not discourses of production; it is production itself. Animal Sentience 25(29)

DOI: $10.51291 / 2377-7478.1475$

Date of submission: 2019-06-02

Date of acceptance: 2019-06-07

(c)

This article has appeared in the journal Animal

Sentience, a peer-reviewed journal on animal

cognition and feeling. It has been made open access,

free for all, by WellBeing International and deposited

in the WBI Studies Repository. For more information,

please contact

wbisr-info@wellbeingintl.org.

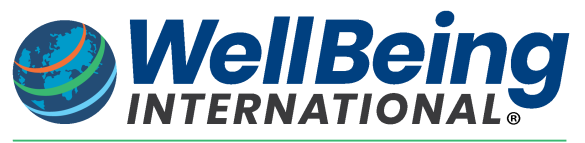

SOLUTIONS FOR PEOPLE, ANIMALS AND ENVIRONMENT 


\title{
The problem is not discourses of production; it is production itself
}

\author{
Commentary on Marino \& Merskin on Sheep Complexity
}

\author{
Sean Hermanson \\ Department of Philosophy \\ Florida International University
}

\begin{abstract}
The mistreatment of sheep is not because of fables, stereotypes, unconscious cultural paradigms, our collective consciousness, anthropocentricism, human arrogance, or our drive to dominate. Nonetheless, protections for sheep used in research and agriculture ought to be strengthened.
\end{abstract}

\begin{abstract}
Sean Hermanson, Associate Professor of Philosophy, Florida International University in Miami, specializes in philosophy of mind and cognitive science. His work on animals includes articles on bees, monkeys and bats. $\mathrm{He}$ also has interests in the metaphysics of consciousness, introspection, human nature, and implicit bias. Website
\end{abstract}

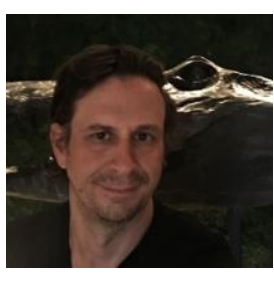

The commentaries on Marino \& Merskin's (2019) article highlight two areas of concern where incremental change would do tremendous good. Woodruff (2019) mentions the absurdity of the Animal Welfare Act's exclusion of sheep as well as birds, rats, mice and other farm animals used in biomedical and other research. Among several helpful suggestions for reform, he urges that the mostly voluntary guidelines prescribed by the Public Health Service be made into regulatory mandates. No doubt seeing these modest protections through will require overcoming vested interests in the political arena. Others criticize the inadequate protections in agricultural contexts for failing to take account of unnecessary pain and distress in the transport of sheep to distant international markets (D'Silva, 2019; Phillips, 2019). These thoughts strike me as humane and reasonable, and I have only two mild points to make about some underlying rationales in the target article and various commentaries.

In her short but sharp response, Vonk (2019) does us all a service by probing the research claims skeptically. No doubt lobbyists for agribusiness will be looking to pounce on exaggerated or selective claims about comparative cognition research. So it is advisable to fashion arguments using the strongest possible foundations. One of Vonk's key takeaways, by my lights, is that we should not be distracted by findings with questionable applicability to animal suffering. When it comes to sheep, what matters most are emotions: "empathy, perspective-taking, prosociality, pessimissim and boredom" - not general intellectual capacities. Another is that a more assiduous approach helps locate insights otherwise overlooked - such as the studies on maternal behavior and aversive treatment.

My only other point is "philosophical." It is less plausible that the mistreatment of sheep can be laid at the feet of ancient prejudices. As argued by Colombo \& Raucea (2019), it is not 
even clear that folklore and fables do stereotype sheep as inert and incapable of being wronged. Despite indispensable cultural paradigms, our collective un/consciousness, our anthropocentricism about mental limitations, our human arrogance, and our drive to dominate, human society has progressed, somewhat. The Animal Welfare Act is not only about "higher" animals: hamsters et al. (perhaps wrongly) are also stereotyped as passive and stupid. But then the difference in protections for guinea pigs and sheep is probably not attributable to the Great Chain of Being ideology. Why are our failings selective? One answer is that they are not always failings. Veterinarians who expressed more concern over chickens than sheep (Marino \& Merskin, 2019) were probably just responding to the fact that the chickens really were treated worse. It is not because of chickens' impressive placement on the Ladder of Being.

Small furry rodents make for cute pets, and the need for legislation to manage times when individuals fail to be responsible stewards isn't countered by a profit-centered industry. Sheep, meanwhile, get the worst of it on both counts. The problem is not discourses of production; it is production itself. Indeed, the 19th amendment did not depend on discovering that women could recognize faces or exploding the stereotype that women are one-dimensional non-individuals. Female, and male, disenfranchisement had more to do with property: early 20th century Pennsylvania and Rhode Island did not care where you placed on a Platonic metaphysical hierarchy; they cared about whether you paid property taxes.

Despite my hesitation to accept every aspect of the diagnosis, I hope Marino \& Merskin's work boosts the call to expand the Animal Welfare Act's coverage and increase protections governing the worldwide trade of sheep.

\section{References}

Colombo, M. and Raucea, C. (2019) Sheep in Aesop's and Phaedrus's fables. Animal Sentience 25(13).

D'Silva, J. (2019) Reflections on sheep rearing. Animal Sentience 25(5).

Marino, L. and Merskin, D. (2019) Intelligence, complexity, and individuality in sheep. Animal Sentience 25(1).

Phillips, C. (2019) Sacrificial lambs. Animal Sentience 25(2).

Vonk, J. (2019) Pulling the wool from our eyes. Animal Sentience 25(3).

Woodruff, M. L. (2019) Smart sheep need more protection. Animal Sentience 25(9). 